\title{
POWER AND CRIME OF OBEDIENCE IN EDUCATION DEPARTMENT-AN EMPIRICAL STUDY OF PAKISTAN
}

\author{
Ahmad Asfand Yar \\ Master of Science in Business Administration, Virtual University of Pakistan \\ Riffut Jabeen \\ Department of Business Administration, Ghazi University, Dera Ghazi Khan \\ Muhammad Ziaullah \\ Department of Business Administration, Ghazi University, Dera Ghazi Khan
}

\begin{abstract}
The purpose of this study was to investigate the effect of power on follower's willingness to commit a "crime of obedience" by complying with a leader's unethical request in organizations of Pakistan. Both variables were considerable importance in the literature of Management. Research framework consists of five hypotheses. Data was collected with a survey from 150 employees of Education Department of Pakistan. Multiple Regression analyses were conducted to investigate the proposed model. The results indicate that power is an important component in obedience to authority. Findings suggest that all five FrenchRaven bases of power are positively related with an intention to commit a crime of obedience. Results are discussed in relation to research on obedience to authority. When power is used by authority, individuals may obey in ways which are destructive and against their personal, moral values. The study has the wide scope for its implementation. On the basis of research findings, the government can modify their policies to get rid of the crime of obedience in the educational sector of Pakistan.
\end{abstract}

Keywords: Crime of obedience, Coercive power, Expert power, Reward power, Referent power

\section{Jel Classification:K11, K12, K13}

*The material presented by the author does not necessarily portray the view point of the editors and the management of the Ilma University - Formerly IBT

1. Ahmad Asfand Yar: ahmadasfandkhan@gmail.com

2. Riffut Jabeen: riffit_jabeen2011@hotmail.com

3. Muhammad Ziaullah: mzaiullah@yahoo.com

CILMA-JBS is published by the Ilma University - Formerly IBT

Main Ibrahim Hydri Road, Korangi Creek, Karachi-75190, Pakistan. 


\section{INTRODUCTION}

The concept of power has been perceived in the social science for quite some time (Clay, 2010). According to French and Raven (1959), in our society, the processes of power are omnipresent, multifaceted and often appalled. In an organization, power is the desire to influence, give orders and carry them out. French and Raven (1959) identified five sources of power which are labeled as a legitimate power, reward power, coercive power, expert power, and referent power. Power is the ability to influence others based on admiration, respect, loyalty and affection. Clay (2010) demonstrates that power is a force that has shaped human history. Most of the people possess power but they do not know about it (Truter, 2008). Power is a factor that can alter human behavior in some given situation. Fuqua et al. (1998) found that social power can change the attitude beliefs and behavior of people. Organizations are made and run by peoples. Orders are given and obeyed by people of organizations. But there is a propensity to commit crimes of obedience by lower level workers due to the power of executives at top levels of organizations (Hinrichs, 2007).

Crimes of Obedience (COO) take place when a person freely commits the immoral and unlawful order of his leader (Carsten and Uhl-Bien, 2012). The term obedience has a lot of complexities; however, a consistent behavioral relationship indicates an act of obeying of a person means that the person does the same thing what another person tells him/her to do (Milgram, 1965). Authorities are more responsible than subordinates in any organizational hierarchy. Abuse of power defies the concept of mutual dependency of Leadership$\neg \neg$ Followership and value to maintain dignity (Hollander, 1995). Passini and Morselli, (2009) pointed out that, people disobey the request of authority and in explicit circumstances follow ordinary standards, so compliance and noncompliance are not indifference with each other. When the act of violence (or illegal order) are ordered or lawful authorities allow these value, the promptness of people to obligate such values is improved (Hamilton and Kelmin, 1989). In this situation, individuals are compelled to follow the commands of the establishment, because they have no other option as long as they acknowledge the authority of the commands. According to Pakistan National Corruption Survey (2009), in Pakistan, the most dishonest government organizations are including police, land, education, health, customs, and judiciary. In Pakistan, organizations in Public sector track a bureaucratic makeup (Bashir et al., 2011). Bosses in Pakistan consider their subordinates as a private servant and it is thought that they will follow the commands, no matter right or wrong, lawful or unlawful (Bashir et al., 2011). It is perceived that in public sector organizations of Pakistan followers always obey the unethical demand of their leaders. The endeavor of the study is to inspect the effect of leader's power on intention to commit a crime of obedience by followers in Government organization of Pakistan. There are studies in the literature about the obedience of authority (Milgrams, 1974), follower propensity to commit crimes of obedience (Hinrichs, 2007), perspectives on obedience to authority (Miller et al., 1995), and Followership belief and crime of obedience (Carsten and Uhl-Bien, 2012).

The act performed in the response of unlawful and immoral orders given by powerful persons (authorities), the crime of obedience (COO) occurred in organizations (Kelman and Hamilton 1989). When a person eagerly commits the immoral and unlawful orders of his/ her leader, the crime of obedience(COO) takes place (Carsten and Uhl-Bien, 2012). The term obedience has a lot of complexities; however a consistent behavioral relationship indicates it as an act to obey, means that a someone performs the same thing what another person (authority) orders him/ her to perform (Milgram, 1965). For the development of public sector organizations in Pakistan, it is necessary to assess the effect of power on the willingness to 
commit a crime of obedience to authority. Keeping these problems in view, following are the objectives of this study.

- To determine the effect of legitimate power on the intention of employees to commit a crime of obedience in government organization of Pakistan.

- To determine the effect of reward power on the intention of employees to commit a crime of obedience in government organizations of Pakistan.

- To determine the effect of coercive power on the intention of employees to commit a crime of obedience in government organizations of Pakistan.

- To determine the effect of expert power on the intention of employees to commit a crime of obedience in government organizations of Pakistan.

- To determine the effect of referent power on the intention of employees to commit a crime of obedience in government organizations of Pakistan.

\section{LITERATURE REVIEW AND RESEARCH HYPOTHESES}

Power is an ability to influence others. According to French and Raven (1959), in our society, the processes of authority are persistent, multifaceted and often disgusted. The capability of one personality to manipulate the activities of another person is a power of obedience (Truter, 2008). In an organization, power is the desire to influence, give orders and carry them out and use to manage relationships. Effective leaders always recognized the importance of developing their own personal power in an organization. Furthermore, French and Raven (1959) identifies five sources of authority and its strengths.

The crime of Obedience- The term obedience has a lot of complexities; however, a consistent behavioral relationship indicates it is an act of obeying. A person performs in the same way as another person (authority) orders him/her to perform (Milgram, 1965). When in the response to commands from a given authority a person perform such act that is considered as unlawful and immoral by a large community is known as the crime of obedience (Kelman and Hamilton, 1989). Crimes of Obedience (COO) take place when a person eagerly commits the immoral and unlawful order of his leader (Carstenand Uhl-Bien, 2012).Hamilton and Sanders (1995) explore the crime of obedience and conformity in the workplace. It is evaluated that obedient actor consider themselves as least responsible for the act; however, individuals who are higher in any hierarchy or having more authority are more responsible for any negative outcome. Authorities are more responsible than subordinates in any organizational hierarchy.

\subsection{Legitimate power and intention to commit a crime}

This is an individual power to influence other's performance and actions. This power is gained by the position that person cleave to the institute (Lunenburg, 2012). French and Raven (1959) describe that legitimate power is a power that comes from internal values in a person "P". Another person "o with lawful right to influence " $\mathrm{P}$ " order these values " in the organization and it is an obligation of " $p$ " to follow those values as ordered by "p". A legitimate power is known as authority that is formally given by the organization. Legitimate power is generally exercised along with the designation of that power. The element of legitimacy create a perception of legitimacy in the minds of followers and they feel powerless as if they have no alternative but to comply with their leader's instructions (Tyler, 1997).Because of this power of authority, followers(employees) in organizations may follow them in such ways which are negative and against their moral and personal values. 
Legitimate power is an authoritative power that involves command by individuals or collective actors and leads to conscious obedience by subordinates (Mann, 1986). People who follow the persons with legitimate powers believe they are too weak to argue against the immoral demands of the persons with legitimate authority (Biggart and Hamilton, 1984).

Legitimate power is an authoritative power that involves command by individuals or collective actors and leads to conscious obedience by subordinates (Mann, 1986). Followers obey the immoral and unlawful demands of these legitimate authorities (Biggart and Hamilton, 1984). Legitimate power can create dissatisfaction, resistance, and frustration among employees which leads to negative effects on creativity (Lunenburg, 2012). Obedience deals with following the commands given by authorities in the organization (Bocchiaro and Zamperini 2012). It is well-known fact that when the act of violence are ordered or permitted by legitimate authority, people readiness to commit is enhanced (Kelmanand Hamilton, 1989). So followers feel powerless as if they have no alternative but to comply with the commands of their leaders (Tyler, 1997).

H1: Legitimate power has a significant impact on the intention of employees to commit a Crime of Obedience.

\subsection{Reward power and intention to commit a crime}

The capacity to award other people what they want is known as reward power and in exchange, you asked them to do things for you. This reward can be anything that other person value. This reward can be financial pay raises, bonuses and non-financial including favorable work assignment, promotion, praise, and recognition. Reward power leads to better performance and employee link the rewards with the performance (French and Raven, 1959). By using 360-degree feedback, employees can also gain reward power over their managers (McShane and Glinow, 2011). The power to reward is used by leaders to hold legitimate power, when employees are rewarded they may respond in kind by carrying through orders (Gibson et al., 1991). If subordinates perceive the reward valuable and supervisor as a trustworthy source of reward, they show obedience (Yukl, 2000).

The capacity to offer people what they want, in exchange you asked them to obey you and to do things for you, is reward power (French and Raven, 1959). It is used to support legitimate power, when employees are rewarded they may respond in kind by carrying through orders (Gibson et al., 1991).

$\mathrm{H} 2$ : Reward power has a significant impact on the intention of employees to commit a Crime of Obedience.

\subsection{Coercive power and intention to commit a crime}

The ability to punish the subordinates gives a manager a great power. Punishment range including termination, suspension, and unpleasant job assignments. This power is known as coercive power and this is distinguished from reward power (French and Raven, 1959). As reward power augment the desirability between supervisor and his assistant employees, in contrast to this coercive power decreases this attraction. The physical harm is often used to demonstrate when the compliance is not gained. If the person confiscate something of constructive value mean that he/she have coercive power over others and if he/ she remove something of negative value mean that the person have reward power over that individual (Lunenburg, 2012). Threats are a typical exercise of destructive power, and the 
military is an example of an institution organized around destructive power (Boulding, 1989). Punishment tends to increase the cost of crime, hence tends to serve as a deterrent (Haag, 1975).

The ability to punish the subordinates gives a manager a great power (French and Raven, 1959). Bullying is enacted through the coercive power and workplace bullying is a hostile and unethical communication directed by one or more individuals towards one individual who is pushed into helpless and defends-less position (Leymann, 1996). Coercions are a usually used to exercise destructive power, and armed force is an instance of an organization structured around destructive power (Boulding, 1989). Punishment tends to increase the cost of crime, hence tends to serve as a deterrent (Haag, 1975).Coercive authority can make an individual commit terrible act without question because the choice to disobey could lead to punishment. It is observed that a crime against humanity has occurred more often as a result of obedience than due to any other form of rebellion by the use of coercive power (Potgieter, 2000). It is observed that targets of coercive power dislike this threat of punishment as they obey and accept it forcefully (Raven, 2008).

H3: Coercive power has the significant impact on employees' intention to commit a Crime of Obedience.

\subsection{Expert power and intention to commit a crime}

Expert power is defined as the influence exercised on the basis of expertise, knowledge and special skills. Physician and Doctors wield expert power. In an organization's hierarchy, any person with low rank may possess expert power. It is essential to have the expert power of employees at all level of the hierarchy of an organization (Luthans, 2011). Before exercise the expert power, followers must perceive the power holders as honest, relevant and credible (Luthans, 2011). When power holder is not the member of follower group then the power is called informational power (French and Raven, 1959). Expert power and referent power are more diffuse in their effect, these sources of power are not directly commanded, not authoritative, and so people are constrained to act in definite ways (Mann, 1986). Luthans (2011) stated that before exercise the expert power, followers must perceive the power-holders as honest, relevant and credible. Expert power has an importance for acceptance the supervisor direction among technical staff (Lee, 2008). The ability to persuade others based on admiration, respect, loyalty and affection is referent power (Craig and Dauglas, 2006). French and Raven (1959) illustrated that greater the attraction between target person and agent, greater the identification and consequently greater the referent power. Referent power deals with appealing personality, people desire to be friendly with power holder. The relationship is based on trust (Craig and Dauglas, 2006).

H4: Expert power has significant impact on intention of employees to commit a Crime of Obedience

\subsection{Referent power and intention to commit a crime}

The ability to persuade others on the basis of admiration, respect, loyalty and affection is referent power. Research shows that celebrities have the power to influence your choices (Craig and Dauglas, 2006). Its base is identification with that person who has some desirable resources and personality traits. French and Raven (1959) illustrate that greater the attraction between target person and agent, greater the identification and consequently greater 
the referent power. Referent power deals with appealing personality, people desire to be friendly with power holder. The relationship is based on trust (Craig and Dauglas, 2006).

Expert power and referent power are more diffuse in their effect, these sources of power are not directly commanded, not authoritative, and so people are constrained to act in definite ways (Mann, 1986). Referent power and expert power give the supervisory relationship a leadership oriented. People respect the expertise of their supervisors. Supervisees feed led rather than bossed so supervisees hold information to counterbalance the power of supervisors with the power of their own (Kadushin and Harkness, 2014).It depends on the personality and reliability of the person that how much referent power he/ she have. It is said that actions have more strength than words "actions speak louder than words". The person who tries to show himself / herself friendly but manipulates and exploits people will lose referent power (Yukl, 2000).

H5: Referent power has the significant impact on the intention of employees to commit a Crime of Obedience.

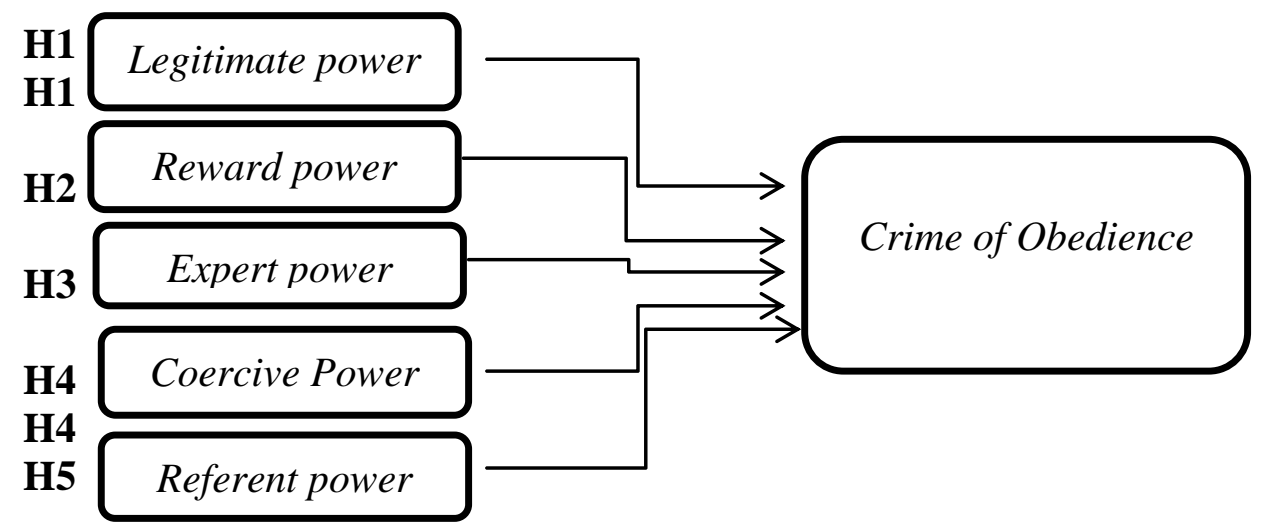

RESEARCH ME

Figure .1:Research Framework

\section{RESEARCH METHODOLOGY}

The study intends to explain the impact of the independent variable (power) on the dependent variable (crime of obedience). Therefore positivistic research paradigm was selected based on deductive reasoning as per this paradigm hypothesis were devised before data collection.

\subsection{Population and sampling frame}

All the teachers from Secondary Schools, Elementary Schools, Senior Elementary School, Primary School, Postgraduate Colleges academic staff and Clerical Staff of Government Education Sector of District Dera Ghazi Khan, District Layyah, and District Rajanpur, Punjab Pakistan are included in the target population. Moreover, the sample frame consists of an up-to-date list of SST's, SEST's, EST's, PSTs and Clerical Staff of this department. 


\subsection{Sample size}

The sample size of this study was 150 . This size was chosen according to the rule of thumb. The standard statistical recommendation is to have a minimum sample size of 100 for a correlation design (Keel, 2007). Earlier, a sample of 149 has been used by Bocchiaro and Zamperini (2012) to determine the dynamics of disobedience and whistle-blowing. Hence our sample size is consistent with prior research.

\subsection{Sampling technique}

A Proportionate Stratified Sampling Technique was used to obtain data from elements. This is a probability sampling technique wherein the population of the study was partitioned into three strata or districts (District Dera Ghazi Khan, District Layyah, and District Rajanpur). Elements were selected from each stratum by a random procedure.

\subsection{Instrument development}

This research is based upon survey method. Questionnaires were only the tool of data collection because it motivates and encourages the respondents to become involved inside. Furthermore, this tool can help to increase the response rate because a set of questions in a systematic way were carried out. Five bases of power given by French-Raven were calculated by using a scale devised by Rahim "Rahim Leader Power Inventory" (1988). The scale was comprised of 29 items. Respondents were asked to express their opinion on the five-point Likert scale, where (1= strongly disagree, $2=$ disagree, $3=$ undecided or natural, $4=$ agree, and $5=$ strongly agree). 6 items were related to find the effect of legitimate power,

- 6 items were related to find the effect of reward power.

- 5 items were related to find the effect of coercive power.

- 6 items were related to find the effect of expert power.

- 6 items were related to find the effect of referent power.

e.g "My superior can suspend me if I am habitually late in coming to work", My superior can suspend me if I am habitually late in coming to work", My superior can fire me if I neglect my duties". ,'I like the personal qualities of my superior".

The reliability of this scale in previous studies was found to be 0.87 (Banerjee, 2009). The crime of Obedience (COO) was measured by the single-item scale, Carsten and Uhlbien, (2012) had already used this item in his study and it this scale has shown good reliability ranging from .73 to .84 in previous studies. Participants of the study were asked about their agreeableness with the following statement: "I would obey my manager's request." This single-item instrument was developed by Carsten, and Uhl-bien, (2012) for their research work. Well-developed single-item measures might be appropriate by comparing multiple-item (Gardner et al., 1998) and it can provide equally valid ratings (Loo, 2002).

\section{DATA ANALYSIS AND DISCUSSION OF RESULTS}

There were 150 respondents in total who were selected with the help of proportionate stratified sampling method. There were 7811 elements from district D.G .khan and 7292 elements from district Layyah while 4679 were from district Rajanpur. Proportionate sample size is $40 \%, 37 \%$ and $23 \%$ for D.G .Khan, Layyah, and Rajanpur 
respectively. There was 60 respondent from D.G. Khan and 55 from Layyah while reaming 35 were identified from district Rajanpur.

From respondents, there were $65 \%$ male and $35 \%$ female $.32 \%$ of the respondents were within the age bracket of 47-60 years and it was followed by (34\%) from 34-46 year of age bracket. Remaining 34\% was from 20-33 year of age. Furthermore, they were analyzed as per their length of service. These results are summarized in Table 1.

Table .1: Respondent's characteristics $(n=150)$

\begin{tabular}{|l|l|l|}
\hline Respondent's characteristics & Classifications & Ratio \\
\hline \multirow{5}{*}{ Gender } & Male & $65 \%$ \\
\cline { 2 - 3 } & Female & $35 \%$ \\
\hline \multirow{5}{*}{ Age(years) } & $20-33$ & $34 \%$ \\
\cline { 2 - 3 } & $34-46$ & $34 \%$ \\
\cline { 2 - 3 } & $47-60$ & $32 \%$ \\
\hline \multirow{5}{*}{ Service length } & Secondary school teachers & $27 \%$ \\
\cline { 2 - 3 } & Senior elementary school teachers & $13 \%$ \\
\cline { 2 - 3 } & Elementary school teachers & $33 \%$ \\
\cline { 2 - 3 } & Primary school teachers & $17 \%$ \\
\cline { 2 - 3 } & Clerks & $10 \%$ \\
\hline Organizations & $1-10$ years & $36 \%$ \\
\cline { 2 - 3 } & $11-20$ years & $255 \%$ \\
\cline { 2 - 3 } & $21-$ above & $39 \%$ \\
\hline
\end{tabular}

In Table 2 mean, standard deviation, reliability coefficient and correlations for all variables are summarized. Correlation analysis disclosed that power dimensions are positively correlated with a crime for obedience. Cronbach's alpha values were determined to measure the internal consistency of the scales and these values are reliable and consistent with values reported in previous research. It was also found that these measures are reliable. Results are summarized and can be seen in a glance in the table given below:

Table .2: Summary Statistics, Alpha Reliability and Correlations

\begin{tabular}{|l|l|l|l|l|l|l|l|l|}
\hline Variable & Mean & S.D & LP & RP & CP & EP & RP & CO \\
\hline Legitimate power & 3.879 & 0.468 & $\mathbf{( . 8 3 )}$ & & & & & \\
\hline Reward power & 3.352 & 0.675 & $.341^{* *}$ & $\mathbf{( . 8 4 )}$ & & & & \\
\hline Coercive power & 2.725 & 0.601 & $.331^{* *}$ & .100 & $\mathbf{( . 7 7 )}$ & & & \\
\hline Expert power & 3.698 & 0.650 & $.380^{* *}$ & .620 & $.373^{* *}$ & $(.74)$ & & \\
\hline Referent Power & 3.458 & 0.223 & $.301^{* *}$ & .110 & $.390^{* *}$ & .071 & $\mathbf{( . 8 2 )}$ & \\
\hline Crime of Obedience & 4.280 & .715 & .259 & .304 & .217 & .433 & .578 & $\mathbf{( . 8 5 )}$ \\
\hline
\end{tabular}

According to Özdamar (1999), the scale is reliable if the Crone Bach's Alpha internal consistency coefficient is between .80 and $1.00(.80 \leq \alpha<1.00)$. Accordingly, the questionnaire of this study can be accepted as a reliable tool of measurement.

Further, the study results show that the legitimate power has highest value of mean than other four bases of power $(\mathrm{M}=3.879, \mathrm{SD}=0.468)$. However, reward power $(\mathrm{M}=3.352, \mathrm{SD}$ $=0.675)$, coercive power $(\mathrm{M}=2.725, \mathrm{SD}=0.601)$ expert power $(\mathrm{M}=3.598, \mathrm{SD}=0.650)$, and referent power $(\mathrm{M}=3.458, \mathrm{SD}=0.223)$ also indicated their value of mean above 
average. Table 3 indicated that intention to commit a crime of obedience has very enormous mean value $(\mathrm{M}=4.280, \mathrm{SD}=0.715)$.

\subsection{Hypothesis testing}

The value of $\mathrm{F}$ is 12.778 which show the significance of the model. As the criteria are that it should be greater than 5 , which is fulfilled in this model and P-value $<0.05$ which is also supporting this statement. It is said that value of adjusted R2 is considered significant if it is less than 0.8. In this model value of adjusted R2 is .200. The value of Durbin Waston in the analysis is 1.947 which is near to 2 and show that the results are significant. DurbanWatson value 2 or near to 2 shows that there is no issue of auto correlation.

Table.3: Model Summary

\begin{tabular}{|l|l|l|l|l|l|}
\hline Model & R & R square & Adjusted R square & Std.error of estimate & Durbin waston \\
\hline & .464 & .216 & .200 & 6.550 & 1.947 \\
\hline
\end{tabular}

Predictors :( constant) Reward power, legitimate power, Coercive power, Referent power, Referent power

Dependent variable: Crime of Obedience Table 4 Beta values show how much a dependent variable is affected by the independent variable. Results support the entire proposed hypothesis. The relationship between legitimate power and intention to commit a crime of obedience with highly acceptable significant value (beta $=0.259, \mathrm{p}=0.001$ ). There is a strong positive relationship between intention to commit a crime of obedience and reward power with highly acceptable significant value (beta $=0.304, \mathrm{p}=0.000$ ). Coercive power is also shown a positive relationship with willingness to commit a crime of obedience and supported hypothesis 3 (beta $=0.217, \mathrm{p}=0.008$ ) Furthermore, There is strong positive relationship between expert power and intention to commit a crime of obedience with highest significant value (beta $=0.433, p=0.000$ ) Finally, intention to commit a crime of obedience and reward power show strong positive relationship with highly acceptable significant value (beta $=0.578, p=0.000$ ). Moreover, $t$-values should be less than 1.96 and $p$-values should be less than 0.05 . Here considering all the five variables all are showing significant impact with t-values ranging from 13.43 to 8.6 and $\mathrm{p}$ - value $<0.05$.

Table.4: Coefficients and Hypothesized Variables Paths

\begin{tabular}{|l|l|l|l|l|}
\hline Variables Paths & B & p-value & VIF & t-value \\
\hline $\mathrm{LP} \rightarrow \mathrm{COO}$ & .259 & .001 & 1.112 & 10.812 \\
\hline $\mathrm{RP} \longrightarrow \mathrm{COO}$ & .304 & .000 & 1.246 & 11.286 \\
\hline $\mathrm{CP} \rightarrow \mathrm{COO}$ & .217 & .008 & 1.048 & 13.438 \\
\hline $\mathrm{EP} \rightarrow \mathrm{COO}$ & .433 & .000 & 1.231 & 8.623 \\
\hline $\mathrm{RP} \rightarrow \mathrm{COO}$ & .578 & .000 & 1.191 & 8.612 \\
\hline
\end{tabular}

Table. 4 revealed the multi co linearity between (IV) independent variable and (DV) dependent variable. Results indicate that the value of variance inflation factor (VIF) lie between 1.04 to 1.246 for all variables which indicate that there is no multicollinearity between intention to commit a crime of obedience and all five bases of power.

This study aims to investigate the effect of power on intention to commit a crime of obedience in education departments of Pakistan. This was a first research conducted to investigate the leader's power and follower's obedience in education departments Pakistan. 
The previous research revealed that there was a relationship between the coercive power, legitimate power, expert power, reward power and referent power with the intention to commit a crime of obedience (Kelman and Hamilton, 1989; Gibson et al., 1991; Haag, 1975; Kadushin and Harkness, 2014). The findings of the study provide new insight into power and obedience literature. These findings suggest that power is an important component in obedience to authority.

The result of this research is also confirmed that all French-Raven bases of power are positively related with the intention to commit a crime of obedience. These findings are consistent with Kelman and Hamilton (1989) research demonstrating that when the act of violence (or illegal order) are ordered or permitted by legitimate authority, people readiness to commit is enhanced. I found a significant effect of legitimate power on intention to commit a crime of obedience. Followers in government organizations of southern Punjab believe that they are too weak to argue against the immoral demands of their legitimate authority. Legitimate power of authority leaves employees feeling powerless. The findings also suggest that the high rewards by the supervisors in government education sector led to high compliance by the subordinates. We found evidence from previous research, examined that if the reward is valued by the subordinate then compliance is most likely, and it is perceived that the supervisor is a trustworthy source of the reward (Yukl, 2000). Reward power used to support legitimate power (Gibson et al., 1991) when employees are rewarded in government organizations of southern Punjab they respond in kind by carrying through orders.

We also found that high coercive power increases the intention to commit a crime of obedience. These findings are consistent with Potgieter (2000) research revealed that coercive authority can make an individual commit terrible act without question because the choice to disobey could lead to punishment. Threats are also exercised by the superiors in Punjab government education departments as destructive power. The findings also support Haag (1975) study illustrated that punishment tends to increase the cost of crime, hence tends to serve as a deterrent. The positive relationship between expert power and intention to commit a crime of obedience indicated that expert power is not used effectively in government academic organizations of Pakistan. Positive impact on team productivity can be observed if expert power is to be used effectively (Lee, 2008). Results indicated that respondents provide the high mean value of expert power variable but the same time, they show more intentions to obey leader's immoral demand. However, the results regarding the effect of referent power on a willingness to commit a crime of obedience are contrary to Craig and Dauglas (2006) research demonstrated that referent power deals with appealing personality, people desire to be friendly with power holder and the relationship is based on trust. But findings of this study indicated that employees in government academic organizations are more willing to commit the crime of obedience to authority that has high referent power.

The results of this study have significant theoretical implications. Results had shown that all five basis of superior power increase the follower's intention to obey leader's unethical or illegal demand. The results also supported the previous research on the relationship between legitimate authority and obedience (Tyler, 1997; Kelman and Hamilton, 1989; Biggart and Hamilton, 1984). When power is used by authority, individuals may follow the authority in ways which are negative and against their individual and ethical values. 


\section{CONCLUSIONS}

Most studies revealed that there was a relationship between the coercive power, legitimate power, reward power, referent power and expert power with the intention to commit a crime of obedience. This study takes a starting point to investigate the effect of power on intention to commit a crime of obedience in Pakistan. The results of the study are confirmed that all bases of power are positively related to intention to obey the unethical demand of superior. The findings suggest that legitimate power of authority leaves employees feeling powerless. Employee's readiness to commit illegal orders by the legitimate authority is increased. The findings also suggest that the high rewards by the supervisors in government education sector led to high compliance by the subordinates. Further, these findings are consistent with Potgieter (2000) research revealed that coercive authority can make an individual commit terrible act without question because they perceived that choice to disobey could lead to punishment.

The positive relationship between expert power and intention to commit a crime of obedience indicated that expert power is not used effectively in government organizations of Pakistan. Finally, findings of this study indicated that employees are more willing to commit the crime of obedience to authority that has high referent power.

It is also observed that there are also few limitations of this study that must be addressed in future by researchers. It is recommended that other should now consider the same type of research and results should be compared to the provinces. The comparison will expose the actual outcome. Researchers should also try to investigate the other situational factors that may effect on intention to commit a crime of obedience. Future research might be conducted to examine the impact of power on intention to commit a crime of obedience in other sectors also.

\section{REFERENCES}

Banerjee, M. (2009) Subordinate Perception of Leadership Style and Power: A CrossCultural Investigation. (Electronic Thesis or Dissertation).

Bashir, S., Khattak, H. R., Hanif, A. and Chohan, S. N. (2011) Whistle-blowing in public sector organizations: Evidence from Pakistan. The American Review of Public Administration. 41(3). pp. 285-296.

Biggart, N. W., and Hamilton, G. G. (1984) The power of obedience. Administrative Science Quarterly. 29. pp. 540-549.

Bocchiaro, P. and Zamperini, A. (2012) Conformity, obedience, disobedience: The power of the situation. In: Psychology - Selected Papers. G. Rossi (ed.). InTech.

Boulding, K. E. (1989) Three faces of power. Newbury Park. Calif: Sage Publications. Chicago.

Carsten, M. K. and Uhl-bien, M. (2012) Ethical Followership: An Examination of Followership Beliefs and Crimes of Obedience. Journal of Leadership \& Organizational Studies. 20(1). pp. 49-61.

Clay, W. (2010) The Effect of Power on Exploratory Behavior. VCU Theses and Dissertations. Paper 2067.

Craig, C. S., and Douglas, S. P. (2006) International marketing research (3rd ed.). New York, NY: Wiley.

French, J. R. P. and Raven, B. (1959) The bases of social power. In Cartwright, D. (Ed.). Studies of social power. pp. 150-167. 
Fuqua, E., Rayne, K., and Cangemi, J. (1998) Leadership and the effective use of power. National Forum of Educational Administration and Supervision Journal. 15E.4. pp. 36-41.

Gardner, D. G., Cummings, L. L., Dunham, R. B., and Pierce, J. L. (1998) Single-item versus multiple-item measurement scales: An empirical comparison. Educational and Psychological Measurement. 58. pp. 898-915.

Gibson, J. L., Ivancevich, J. M. and Donnelly, J. H. (1991) Organizations: Behavior, Structure, Processes. Boston, MA: Irwin.

Haag, E. V. (1975) Punishing criminals concerning a very old and painful question. New York: Basic Book. 4.

Hamilton, V. L. and Sanders, J. (1995) Crimes of obedience and conformity in the workplace: Surveys of Americans. Russians and Japanese.Journal of Social issues. 51. pp. 67-88.

Hinrichs, K. T. (2007) Follower propensity to commit crimes of obedience: The role of leadership beliefs. Journal of Leadership \& Organizational Studies. 14. pp. 69-76.

Hollander, E. P. (1995) Ethical challenges in leader-follower relationships. Business Ethics Quarterly. 5. pp. 55-65.

Kadushin, A. and Harkness, D. (2014) Supervision in social work. 5th ed. New York: Columbia University Press.

Keel, J. M. (2007) The relationship between leadership style, work-family interface, and parenting style in police officers. M.S., Northern Kentucky University Kentucky.

Kelman, H. C. and Hamilton, V. L. (1989) Crimes of obedience: Toward a social psychology of authority and responsibility. New Haven, CT: Yale University Press.

Lee, K. L. (2008) Bases of Power and Subordinates' Satisfaction with Supervision: The Contingent Effect of Educational Orientation. International Education Studies. 2(1). pp. 3-13.

Leymann, H. (1996) The content and development of mobbing at work. European Journal of Work and Organizational Psychology. 5 (2). pp. 251-275.

Loo, R. (2002) A caveat on using single-item versus multipleitem scales. Journal of Managerial Psychology. 17. pp. 68-75.

Lundberg, F. C. (2012) Power and Leadership: An Influence Process. International Journal of management, Business and administration. (15). pp. 1-9.

Luthans, F. (2011) Organizational behavior (11th ed.). New York, NY: McGraw-Hill Irwin.

Mann, M. (1986) The Sources of Social Power. Cambridge: Cambridge Policy Press.

McShane, S. L, and Von Glinow, M. A. (2011) Organizational behavior (5th ed.). New York, NY: McGraw-Hill Irwin.

Milgram, S. (1965) Some conditions of obedience and disobedience to authority. Human Relations.19. pp. 57-76.

Milgram, S. (1974) Obedience to authority: An experimental view. New York: Harper \& Row.

Miller, A. G., Collins, B. E., and Brief, D. E. (1995) Perspectives on obedience to authority: the legacy of the Milgram experiments. Journal of Social Issues. 51(3). pp. 1-19.

Passini, S. and Morselli, D. (2009) Authority relationships between obedience and disobedience. New Ideas in Psychology. 27(1). pp. 96-106.

Potgieter, J. (2000) Negotiator Power Authority. Negotiation Academy, UK.

Rahim, M. A. (1988) The development of a leader power inventory. Multivariate Behavioral Research. 23. pp. 491-503.

Transparency International. (2009b) Pakistan National Corruption Perception Survey 2009. Available at http://www.transparency.org (accessed 6 September 2014). 
Truter, I. (2008) Power in the workplace...Put your hand inside a velvet glove. SA pharmaceutical journal. 75 . pp. 50-52.

Tyler, T. R. (1997) The psychology of legitimacy: A relational perspective on voluntary deference to authorities. Personality and Social Psychology Review. 1. pp. 323-345.

Yukl, G. (2000) Use power effectively. In E. A. Rocke (Ed.). Handbook of principles of organizational behavior (pp. 243-256). Oxford, England: Blackwell. 